\title{
Giant verruca vulgaris: a case report
}

\author{
Mona S. Haroen, Herliyani M. Purba, Eddy Kartadjukardi, Sri A. Sularsito \\ Department of Dermatology and Venereology, Faculty of Medicine, University of Indonesia/Dr. Cipto Mangunkusumo Hospital, \\ Jakarta, Indonesia
}

\begin{abstract}
Abstrak
Veruka vulgaris merupakan lesi kulit yang paling sering disebabkan oleh virus papiloma humanis (HPV). Jarang didapatkan lesi berukuran besar, kronik, terisolasi, dan soliter. Kami melaporkan kasus veruka vulgaris raksasa pada seorang pria berusia 66 tahun pada dorsal pedis sinistra yang membesar perlahan dan mengeras dalam 10 tahun. Lesi berupa nodus soliter verukosa, hiperkeratotik, berwarana abu kecoklatan, berbatas tegas, berbentuk bulat berukuran $3 \times 2,4 \times 0,4 \mathrm{~cm}$. Pada pemeriksaan histopatologis terdapat hiperkeratosis/ortokeratosis kompak, banyak koilosit pada lapisan granular dan spinosum atas, akantosis, dan pemanjangan rete ridges yang mengarah ke sentral. Pemeriksaan rantai polimerase (PCR) dan hibridisasi in situ gagal mengidentifikasi DNA HPV. Pasien berhasil diterapi dengan salep asam salisilat 40\%. (Med J Indones 2008; 18: 135-8)
\end{abstract}

\begin{abstract}
Common wart is the most frequent clinical lesion caused by human papillomaviruses (HPVs). Giant, chronic, isolated, and solitary lesion is uncommon. We reported a case of giant verruca vulgaris in a 66 year-old man on left dorsal pedis that slowly enlarged and hardened in 10 years. It was a solitary hyperkeratotic verruca vulgaris, grey brownish in color, circumscribe, round, and $3 \times 2.4 \times 0.4 \mathrm{~cm}$ in size. Histopathologic examination revealed compact hyperkeratosis/ orthokeratosis, many koilocytes in the granular and upper spinous layer, acanthosis, and elongated rete ridges that were pointing radially toward the center of the lesion. Polymerase chain reaction (PCR) and in situ hybridization failed to identify HPV DNA. The patient was successfully treated with salicylic acid 40\% ointment. (Med J Indones 2008; 18: 135-8)
\end{abstract}

Key words: papilloma viruses, hyperkeratosis, orthokeratosis

Warts, or verrucae, are benign proliferations of the skin and mucosa that are caused by papillomavirus infection. ${ }^{1,2}$ The papillomaviruses can be found in human and a number of other species. ${ }^{1}$ Human papillomaviruses (HPVs) belong to the family of Papillomaviridae., ${ }^{3,4}$ All papillomaviruses are highly host-specific, for instance, HPVs only infect human. ${ }^{1}$

HPVs are non enveloped double-stranded, circular, epitheliotropic DNA viruses of which more than 100 different genotypes have been identified. ${ }^{1-4}$ Certain HPV types tend to occur at particular anatomic sites. However, warts of any HPV type may occur at any site. ${ }^{2}$ Often associated with distinct regional predilection, histopathology, and biology, HPV types are divided into three categories: cutaneous (nongenital) types such as HPV-1,-2,-3, and -4; genital-mucosal types such as HPV-6,-11,-16, and -18; and those usually isolated from epidermodysplasia verruciformis such as HPV-5 and $-8 .{ }^{1}$
Cutaneous manifestations of warts are varied, such as common warts (verruca vulgaris/VV), flat warts (verruca plana), and plantar and palmar warts. ${ }^{1}$ Common warts represent the most frequent clinical lesions produced by the HPV. ${ }^{5}$ The clinical manifestation of VV are scaly, rough, spiny papules or nodules, and the size ranges from smaller than $1 \mathrm{~mm}$ to larger than $1 \mathrm{~cm}$ that can be found on any skin surface, most commonly on hands and feet. ${ }^{1,2,6}$

Here, we reported a case with a giant verruca vulgaris that had been present for 10 years on the dorsal of the left foot.

\section{CASE}

A 66 year-old man came to Cipto Mangunkusumo hospital on May 1, 2006. He had a lump on the dorsal of his left foot for more than 10 years. It started as a 
small lump that slowly enlarge and became harder. There was no history of trauma, pain, or itch. He never scratch or rub it. The lump had never been wounded or showed any sign of bleeding. He never get any medical treatment previously.

On dermatologic examination, a solitary verrucous, hyperkeratotic, grey brownish, circumscribe, round nodule of $3 \times 2.4 \times 0.4 \mathrm{~cm}$ with hyperpigmentated surroundings was observed on the lateral side of the dorsal left foot (Figure 1a and 1b). There was no tenderness on palpation.

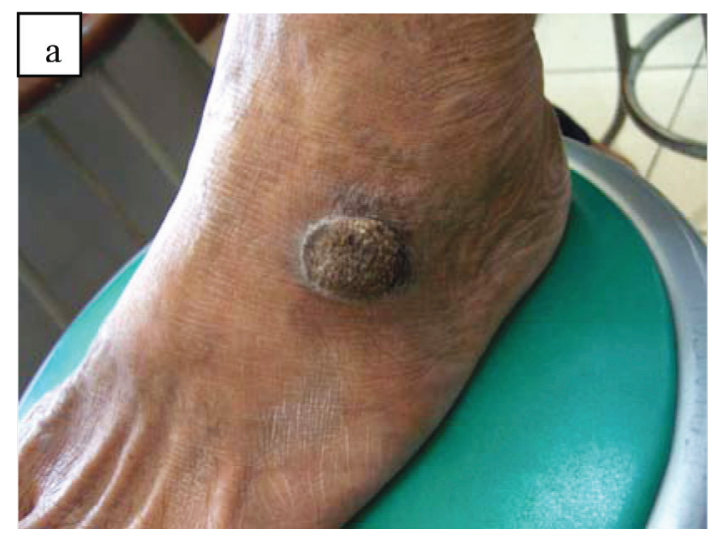

Histopathologic examination revealed compact hyperkeratosis/orthokeratosis, many koilocytes in the granular and upper spinous layer, normal keratohyaline granules, mild hypergranulosis, acanthosis, and elongated rete ridges that pointed radially toward the center. The dermis showed papillomatosis, mild perivascular inflammatory cell invasion and distended deep dermal vessels (Figure 2a and 2b).

Figure 1. a) Solitary verruca vulgaris, hyperkeratotic, $3 \times 2.4 \times 0.4 \mathrm{~cm}$ nodule, b) Close up view
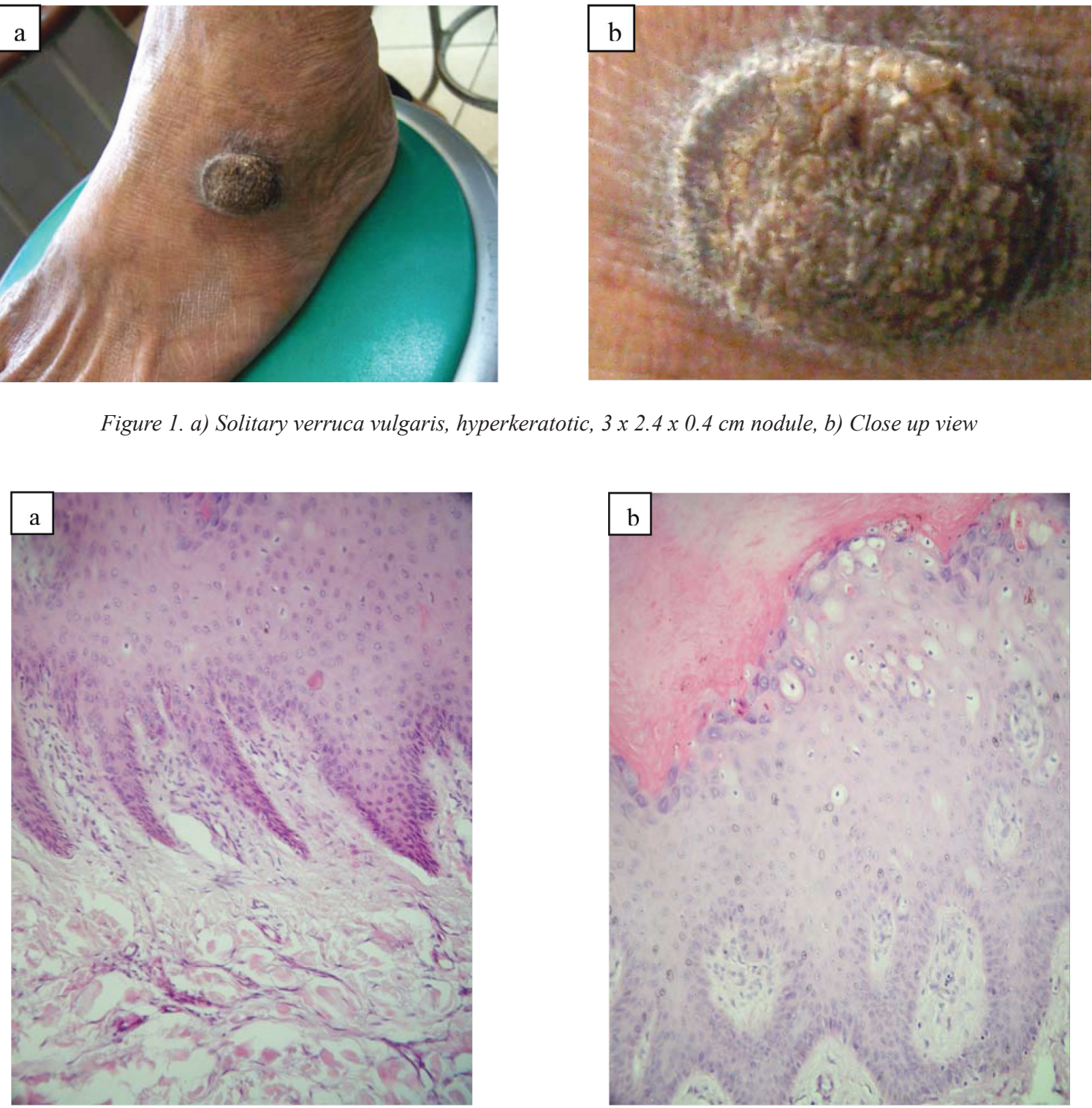

Figure 2. a) Panoramic view of the lesion. There are elongated rete ridges, which pointed radially toward the center of the lesion, b) Higher magnification shows compact hyperkeratosis/orthokeratosis. There are many koilocytes on the granular and upper spinous layer 
The HPV analysis using polymerase chain reaction (PCR) performed on DNA, which was extracted from fresh tissue biopsy, failed to identify any type of HPV as none of the bands had the size of 450 bp (Figure 3). Viral genomic material were also failed to be identified by hybridization.

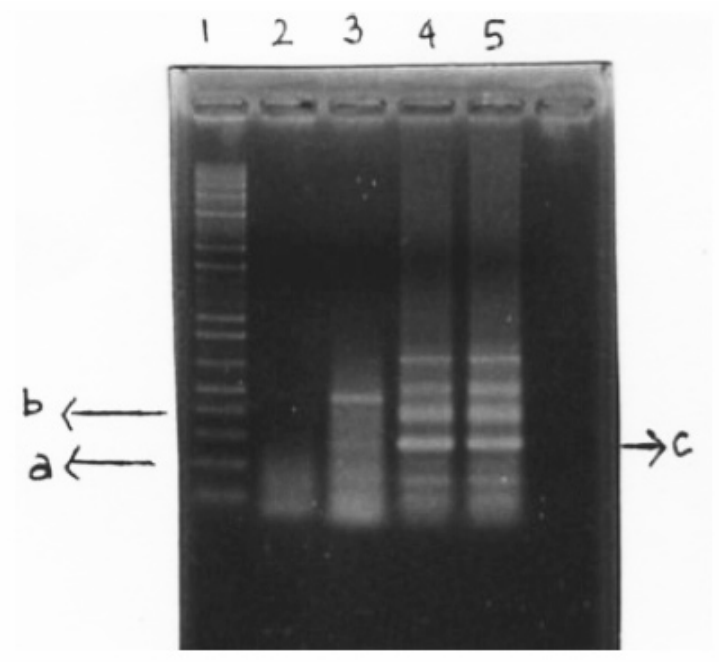

Figure 3. PCR analysis. a. DNA marker of 200 base pairs (bp); b. DNA marker of $400 \mathrm{bp}$; c. Internal control (human $\beta$-globin DNA, 268 bp); 1. DNA marker; 2. Negative control; 3. HPV positive control (450 bp); 4. Sample (general HPV primer); 5. Sample (duplo) (general HPV primer)

Based on the clinical features and histopathologic findings, diagnosis of giant verruca vulgaris was made. The patient was treated with salicylic acid $40 \%$ ointment, and showed a good result (Figure 4).

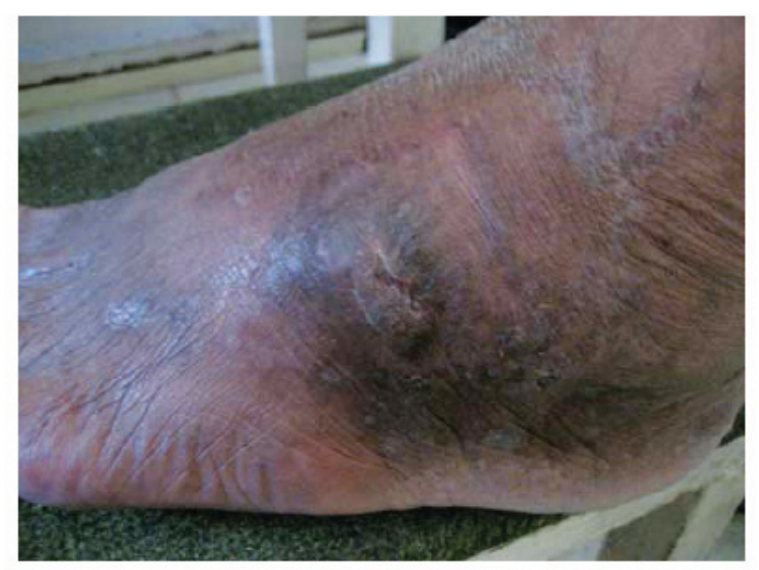

Figure 4. The lesion after treatment with salicylic acid $40 \%$ ointment showed a good result

\section{DISCUSSION}

Verruca vulgaris is one of the clinical manifestation of HPV cutaneous infection. ${ }^{1,2}$ It shows cosmopolite spread and is transmitted through skin contact and autoinoculation. Further, it affects children, adults, and elderly, with no sexual predilection. ${ }^{2,7}$ In our case, the patient was a 66 year-old man with a lump on the dorsal of his left foot that enlarged and became harder in more than 10 years, with no itch or pain, and was diagnosed as VV. Verruca vulgaris usually are asymptomatic, but may cause cosmetic disfigurement.,

Although the lesions are usually 2 to $10 \mathrm{~mm}$ in diameter, they can grow up to a size larger than $1 \mathrm{~cm}^{5}$ Autoinoculation may also occur, causing local spread of lesions. ${ }^{2}$ Our case represented a typical case of VV, but it was a giant VV that was chronic, isolated, and solitair. The diagnosis of wart is made primarily based on the clinical findings. ${ }^{2,7}$

The histopathologic result of our case, was compatible with the histopathological features of $\mathrm{VV}$ that are acanthosis, papilomatosis, and hyperkeratosis. ${ }^{5,7}$ Further, the rete ridges were elongated and at the periphery bent inward so they appeared to point radially toward the center (arborization). ${ }^{5,7}$ The characteristic features that distinguish VV from other papillomas are the presence of foci of vacuolated cells, referred to as koilocytotic cells, vertical tiers of parakeratotic cells, and foci of clumped keratohyaline granules. ${ }^{5,7}$

The HPV infection occurs through inoculation of virus into the viable epidermis through defects in the epithelium. ${ }^{1}$ Common predisposing factors include trauma, biting, and sucking of nails, and scratching. ${ }^{8}$ Further, maceration of the skin is probably an important predisposing factor. ${ }^{1}$ The patient could not recall any trauma to the affected area before the lesion exist. His previous activities also were not related to any condition that could be a possible cause of skin maceration. Minor trauma was then thought to be the predisposing factor of viral inoculation in this case.

Contagion of HPV probably depends on several factors, including the location of lesions, the quantity of infectious virus present, the degree and nature of the contact, and the general and HPV-specific immunologic status of the exposed individual. ${ }^{1}$ The source or reservoir for HPV is believed to be individuals with clinical or subclinical infection, as well as the environment. ${ }^{1}$ In this patient, there was lump on his foot for ten years 
with no history of contact to other individual who had VV. The source of infection was unknown, and contact with individuals with subclinical infection or the environment was then thought to be the source of HPV infection. To establish the chronic infection characteristics of a wart, it is supposed that infection of epidermal stem cells might be necessary. ${ }^{1}$

Verruca vulgaris is often associated with HPV-2, but may also be induced by HPV-1,-3,-5,-7,-10,-26 through -29, and $-41,{ }^{5}$ and PCR may be used to amplify viral DNA for testing. ${ }^{2}$ Although HPV can be detected in younger lesions, it may be absent in older lesions. ${ }^{2}$ In this case, HPV DNA analysis from fresh tissue biopsy using PCR failed to identify HPV DNA that might be due to the old age of the lesion. Viral DNA identification using Southern blot hybridization is sensitive and specific technique to identifiy specific HPV type that is present in tissues. ${ }^{2}$ However, viral genomic material was not identified in this patient, that might be due to the limited number of RNA probes used in hybridization method that only consisted of several types of $\operatorname{HPV}(16,18$, $31,33,35,39,45,51,52,56,58,59,68,6,11,42,43$, and 44).

In $\mathrm{VV}$, many different treatment modalities are available. ${ }^{5}$ The proper approach to the management of warts depends on the age of the patient, the extent and duration of lesions, the patient's immunologic status, and the patient's desire for therapy. ${ }^{1}$ Treatment algorithm should be started with the least painful, least expensive, and least time-consuming methods. ${ }^{5}$ Many kinds of local treatments can be used for warts, but knowledge on the absolute and relative efficacy of those treatment is incomplete. ${ }^{6}$ There are four general approaches: cytodestructive methods, chemotherapeutic compounds, antiviral therapies, and immunotherapy. ${ }^{5}$ This patient was treated with salicylic acid $40 \%$ ointment, because it has never been treated before, and the result was good. Salicylic acid is the first-line therapy used to treat warts with cure rates varied from $70-80 \%{ }^{2}$

In conclusion, the diagnosis of giant verruca vulgaris was made based on the clinical features and histopathological findings. Analysis using PCR and hybridization failed to identify any type of HPV DNA. The virus can be detected in younger lesions, but may be absent in older lesions. Salicylic acid $40 \%$ ointment was used to treat the warts with a good result.

\section{REFERENCES}

1. Lowy DR, Androphy EJ. Wart. In: Freedberg IM, Eisen AZ, Wolf K, Austen KF, Goldsmith LA, Katz SI, editor. Fitzpatrick's dermatology in general medicine. $6^{\text {th }}$ edition. New York: McGraw-Hill, 2003.p.2119-31.

2. Rinker $\mathrm{MH}$, Shenefelt PD. Warts, Nongenital. www. emedicine.com/derm/topic457.htm. Accessed June 5, 2006.

3. Hagiwara K, Uezato H, Arakaki H, Nonaka S, Nonaka $\mathrm{K}$, Nonaka $\mathrm{H}$, et al. A genotype distribution of human papillomaviruses detected by polymerase chain reaction and direct sequencing analysis in a large sample of common warts in Japan. J Med Virol. 2005; 77: 107-12.

4. Zekri ARN, Bahnassy AA, Seif-Eldin WM, El-Din HMA, Madbouly MS, Zidan AZ, et al. Role of human papilloma virus (HPV) in common and genital warts and its relation to P53 expression. J Egyp Natl Cancer Inst. 2005; 17: 117-24.

5. Ergun SS, Su O, Buyukbabany N. Giant Verruca Vulgaris. Dermatologic Surgery. 2004; 30(3): 459-62.

6. Gibbs S, Harvey I, Sterling J, Stark R. Local Treatments for Cutaneous Warts: Systematic Review. BMJ. 2002; 325: 461-8.

7. Sterling JC, Handfield-Jones S, Hudson PM. Guidelines for the Management of Cutaneous Warts. British J Dermatol. 2001; 144: 4-11.

8. Theng TSC, Goh BK, Chong WS, Chan YC, Giam YC. Viral warts in children seen at a tertiary referral centre. Ann Acad Med Singapore. 2004; 33: 53-6. 